\title{
業務用㴻房における調理行動の頻度と作業者の歩行速度の実態調査 FIELD SURVEY ON FREQUENCY OF COOKING OPERATIONS AND WALKING SPEED OF WORKERS IN COMMERCIAL KITCHENS
}

\author{
近藤靖 史 ${ }^{* 1}$, 齋藤 義博*2, 吉野 一*3, 荻田俊輔*4, 藤田 美和子*5 \\ Yasushi KONDO, Yoshihiro SAITO, Hajime YOSHINO, \\ Shunsuke OGITA and Miwako FUJITA
}

\begin{abstract}
In commercial kitchens, it is very important to remove heat, contaminants and odors generated from cooking appliances. When the thermal plume over an appliance is disturbed by airflow due to the HVAC system and/or cooking operations, the hood capture efficiency decreases, and the indoor environment becomes worse. Therefore, these disturbances should be considered when studying commercial kitchen ventilation systems. In Nordtest method VVS088, the hood efficiency is tested with a moving panel to include the effect of disturbance caused by a cook. However, the basis for the speed and frequency of the moving panel is not clear. In this study, frequency of cooking operations and walking speed of workers were examined in five medium-sized electrical commercial kitchens. The results showed that the frequency of cooking operations and the walking speed depended on cooking menu, cooking appliances, workers number and kitchen space. The average of walking speed was $1.45 \mathrm{~m} / \mathrm{s}$ when workers were passing through the area in front of cooking appliances, while the average of walking speed was $1.2 \mathrm{~m} / \mathrm{s}$ when they were leaving or approaching to the area. The walking speed in real kitchens is much faster than moving speed of panel $(0.5 \mathrm{~m} / \mathrm{s})$ in Nordtest method VVS088.
\end{abstract}

Keywords : Commercial Kitchens, Cooking operation, Walking speed, Field Survey, Analysis 業務用厨房, 調理行動, 歩行速度, 実態調查, 解析

\section{1 はじめに}

業務用欴房では調理に伴い、熱・水蒸気・臭気・燃焼排ガスなどが 発生し、大量の換気が必要となる。また、作業空間の快適性や作業効 率を維持するための空調設備が必要である。このため、㕑房内の換 気・空調設備による消費エネルギーが大きく、省エネルギーの必要性 が高い1)。厨房内の換気・空調設備において省エネルギー性能を向上 させるためには、できるだけ少ない換気量で調理機器上の熱上昇流が スムーズに排気フードに捕集される状況を作ることが重要である。こ のためには調理機器周辺の気流場の実態を十分に把握した上で、これ をできるだけ静穏な状態とし、調理機器上の熱上昇流に対する擾乱を 抑制する必要がある。この擾乱の主なものとして、換気・空調用の吹 出し気流による擾乱(以下、空調擾乱と記す)と、調理者の動きに伴う 調理機器上の熱上昇流への擾乱(以下、人体擾乱と記す)の 2 つが挙げ られる。空調擾乱を抑制する方法として置換換気・空調方式が検討さ れている ${ }^{2)}$ 。また、排気フードの袖壁は空調擾乱や人体擾乱による熱 上昇流への影響を緩和する効果があり、米国などでは袖壁の設置が推 奨されている ${ }^{3)}$ 。また、北欧で定められた業務用㕌房内の排気フード の捕集性能試験の技術基準である Nordtest method VVS0884)では幅
$0.5 \mathrm{~m} \times$ 高さ $1.0 \mathrm{~m}$ のパネルを速度 $0.5 \mathrm{~m} / \mathrm{s}$ で $1.0 \mathrm{~m}$ 間を移動させること により人体擾乱を模擬している。ただし、この試験法においてパネル の移動速度や移動頻度(周期)などの規定に関する明確な根拠は示さ れてない。

人体擾乱を組み込んだ業務用厨房の換気・空調システムの研究例と して、国内では百瀬ら ${ }^{5)}$ のネキンを用いた実験や、荻田ら ${ }^{6}$ による 人の歩行を組み込んだ実験があり、前述の Nordtest method VVS088 ${ }^{4}$

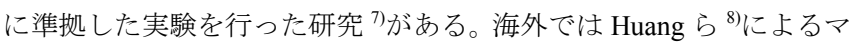
ネキンを用いた研究などが挙げられる。ただし、これらの研究におい ても、人体擾乱の与え方の根拠は明確ではない。一方、住宅厨房を対 象としてレンジ上の横風の影響を検討した例 ${ }^{9), 10}$ がある。また、赤林 $ら^{10)}$ や近藤ら ${ }^{11}$ は住宅厨房において Nordtest method VVS088 $8^{4}$ に準拠 した実験を行い、人体擾乱の影響を検討している。また、倉渕ら ${ }^{12}$ は住宅㕌房において調理者を模擬した擾乱のある条件下で実験を行 い、捕集率が低下寸ることを示している。ただし、これらの研究にお いても適切に人体擾乱を模擬する方法までは検討されていない。 そこで、本研究では 5 つの中規模業務用電化㕌房を対象に、調理行動 を調査し、その頻度や調理者の歩行速度を解析し、人体擾乱の与え方の

\footnotetext{
*1 東京都市大学工学部建築学科 教授 ·博士 (工学)

*2 東京都市大学大学院

*3 東洋熱工業 東京都市大学 客員准教授・博士 (工学)

*4 東洋熱工業 修士(工学)

*5 中部電力エネルギー応用研究所
}

Department of Architecture, Faculty of Engineering, Tokyo City University, Dr. Eng. Graduate School, Tokyo City University

Technical Research Institute, TONETS Co.

Tokyo City University, Dr. Eng.

Technical Research Institute, TONETS Co., M. Eng.

Energy Applications Research and Development Center, Chubu Electric Power Co. 
根拠となり得るデータを整備する。本研究の位置付けを図 1 に示寸。す なわち、本研究では業務用厨房における調理行動の頻度や調理者の歩 行速度のデータを整備する。今後、このデータに基づいて調理行動を 設定した模擬調理実験の結果と、移動パネルを用いた擾乱発生装置に よる実験結果の整合性を確認することにより、排気フードの捕集性状 の試験時における標準的な試験条件として適切な移動パネルの速度 や頻度を求めることができると考えている。

\section{2 調査概要}

表 1 に示す 5 つの中規模社員食堂(設計食数 200 800 食/日)の電化厨房 を調查対象とした。5つの厨房の平面図を図 2 に示す。図 3 のように、 厨房にビデオカメラを設置し、稼㗢時の欴房を撮影し、動画を解析する。 撮影画像の例を図 4 に示寸。調査対象厨房および調査時の食数・メニュー などを表 1 に示す。調查は 1 欴房に対し、2 日間行い、稼働時の厨房内を 撮影した。次に得られた動画から、壓房内における調理者の各調理行動の 頻度および調理者の歩行速度を解析した。

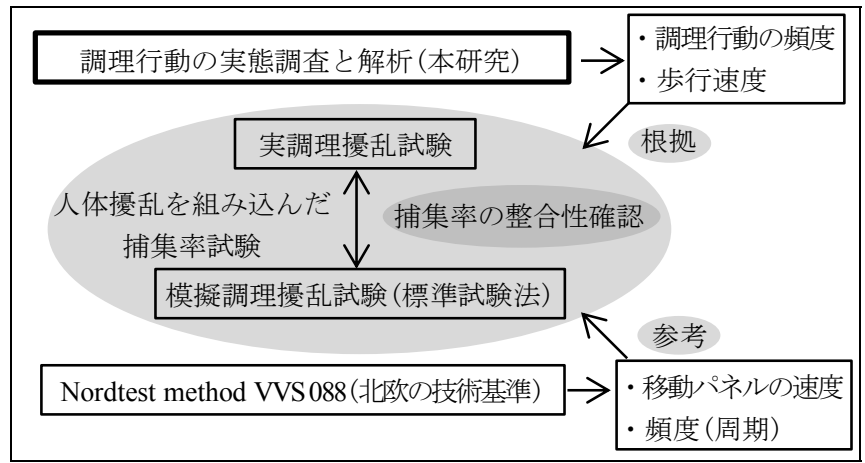

図 1 本研究の位置付け

表 1 調査対象厨房および調査時の食数・メニューなど

\begin{tabular}{|c|c|c|c|c|c|}
\hline & 厨房 A & 厨房 B & 厨房 C & 厨房 D & 厨房 E \\
\hline 床面積 & $75.8 \mathrm{~m}^{2}$ & $111.8 \mathrm{~m}^{2}$ & $70.0 \mathrm{~m}^{2}$ & $97.0 \mathrm{~m}^{2}$ & $127.0 \mathrm{~m}^{2}$ \\
\hline 設計食数 & 約 200 食 & 約 800 食 & 約 200 食 & 約 400 食 & 約 200 食 \\
\hline $\begin{array}{l}\text { 測定期間 } \\
(2012 \text { 年) }\end{array}$ & $\begin{array}{c}12 \text { 月 } 12 \text { 日 } \\
\sim 13 \text { 日 } \\
\end{array}$ & $\begin{array}{c}12 \text { 月 } 5 \text { 日 } \\
\sim 6 \text { 日 } \\
\end{array}$ & $\begin{array}{c}11 \text { 月 } 12 \text { 日 } \\
\sim 13 \text { 日 } \\
\end{array}$ & \begin{tabular}{|c|}
12 月 13 日 \\
$\sim 14$ 日 \\
\end{tabular} & $\begin{array}{c}12 \text { 月 } 4 \text { 日 } \\
\sim 5 \text { 日 }\end{array}$ \\
\hline \multirow[b]{2}{*}{ 提供食数 } & \begin{tabular}{l|l}
$12 / 12$ & $12 / 13$ \\
\end{tabular} & $12 / 5 \quad 12 / 6$ & \begin{tabular}{|l|l|}
$11 / 12$ & $11 / 13$ \\
\end{tabular} & \begin{tabular}{|l|l|}
$12 / 13$ & $12 / 14$ \\
\end{tabular} & \begin{tabular}{l|l|}
$12 / 4$ & $12 / 5$ \\
\end{tabular} \\
\hline & \begin{tabular}{l|l}
78 & 73 \\
食 & 食 \\
\end{tabular} & \begin{tabular}{c|c}
195 & 165 \\
食 & 食 \\
\end{tabular} & \begin{tabular}{c|c}
145 & 140 \\
食 & 食 \\
\end{tabular} & \begin{tabular}{|c|c|}
324 & 294 \\
食 & 食 \\
\end{tabular} & \begin{tabular}{c|c}
193 & 185 \\
食 & 食 \\
\end{tabular} \\
\hline 作業人数 & 3 人 & 2 人 & 7 人 & 7 人 & 6 人 \\
\hline 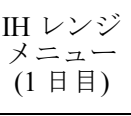 & \begin{tabular}{|} 
|茹で野菜 \\
味噌汁
\end{tabular} & $\begin{array}{l}\text { |根の } \\
\text { 惹 } \\
\text { 物ぼろ } \\
\text { 野菜炒め }\end{array}$ & $\begin{array}{l}\text { 煮物 } \\
\text { 味噌汁 } \\
\text { 茶 }\end{array}$ & 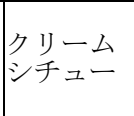 & $\begin{array}{l}\text { 若竹惹 } \\
\text { 柳焼き }\end{array}$ \\
\hline $\begin{array}{l}\mathrm{IH} \text { レンジ } \\
\text { メュー } \\
(2 \text { 日目 })\end{array}$ & 味䁚汁 & \begin{tabular}{|l} 
煮物 \\
ス プ \\
野菜炒め
\end{tabular} & $\begin{array}{l}\text { 味噌汁 } \\
\text { スプ } \\
\text { 煮物 }\end{array}$ & $\begin{array}{l}\text { そばつゆ } \\
\text { 白米 }\end{array}$ & $\begin{array}{l}\text { ポトフ } \\
\text { 豚肉の } \\
\text { 生姜焼 } \\
\end{array}$ \\
\hline $\begin{array}{l}\text { 茹で麺器 } \\
\text { メニュ } \\
(1 \text { 日目) }\end{array}$ & |ラーメン & ラーメン & \begin{tabular}{|l} 
そば \\
うどん \\
ラーメン
\end{tabular} & ラーメン & 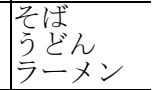 \\
\hline $\begin{array}{l}\text { 茹で麺器 } \\
\text { メニュ } \\
\text { (2 日目) }\end{array}$ & そば & \begin{tabular}{|l} 
そはば \\
うどん
\end{tabular} & 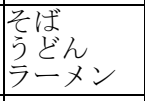 & きしめん & $\begin{array}{l}\text { ぞば } \\
\text { うどん } \\
\text { ラーメン }\end{array}$ \\
\hline $\begin{array}{l}\text { フライヤ } \\
\text { メニュ } \\
\text { (1 日目) }\end{array}$ & $\begin{array}{l}\text { コロッケ } \\
\text { かぼちゃ } \\
\text { の天ぷら }\end{array}$ & 白身魚 & $\begin{array}{l}\text { 鶏の } \\
\text { 唐揚げ }\end{array}$ & $\begin{array}{l}\text { 白身フライ } \\
\text { コロッケ }\end{array}$ & $\begin{array}{l}\text { 市・ } \\
\text { かぼちゃ. } \\
\text { サツマイモ } \\
\text { の天ぷら、 } \\
\text { コロッケ } \\
\end{array}$ \\
\hline $\begin{array}{l}\text { フライヤ } \\
\text { メニュ } \\
(2 \text { 日目 })\end{array}$ & \begin{tabular}{|l} 
ちくわ天 \\
白身フライ \\
コロッケ
\end{tabular} & $\begin{array}{l}\text { かき揚げ } \\
\text { コロッケ } \\
\text { メンチカツ }\end{array}$ & $\begin{array}{l}\text { 厚揚げ } \\
\text { コッッ } \\
\text { レンコン } \\
\text { フライ } \\
\end{array}$ & $\begin{array}{l}\text { 揚げナス } \\
\text { 身フライ }\end{array}$ & から揚げ \\
\hline
\end{tabular}

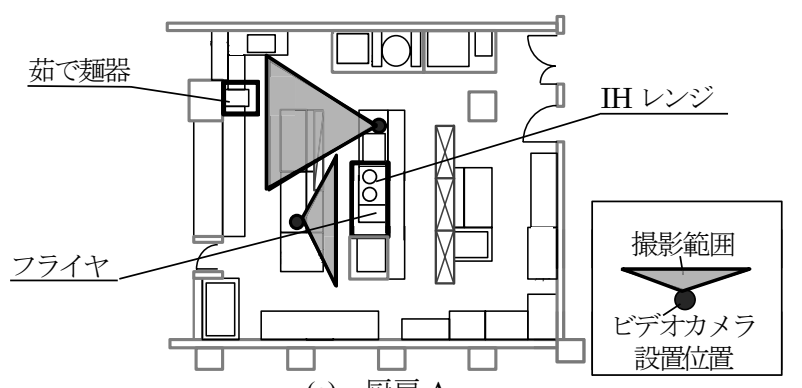

(a) 㕌房 $\mathrm{A}$

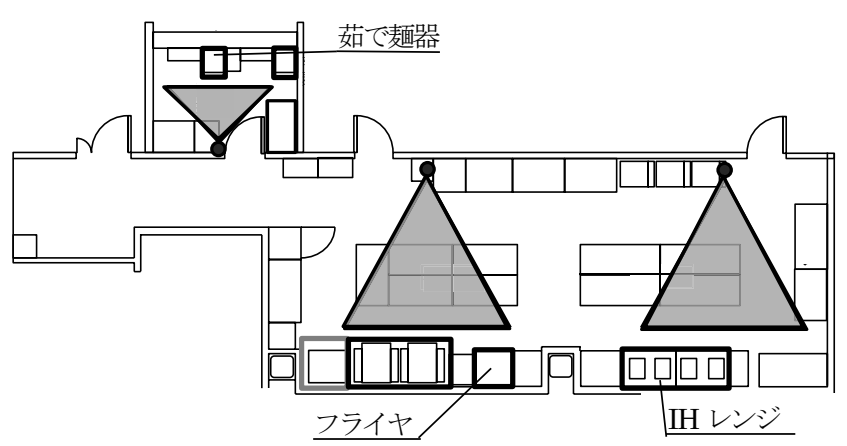

(b) 厨房 $\mathrm{B}$

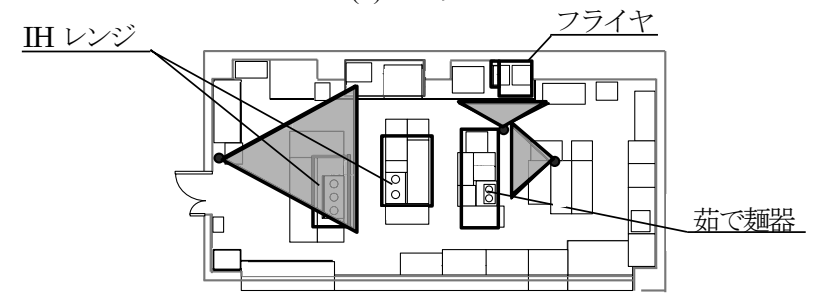

(c) 嘚房 $\mathrm{C}$

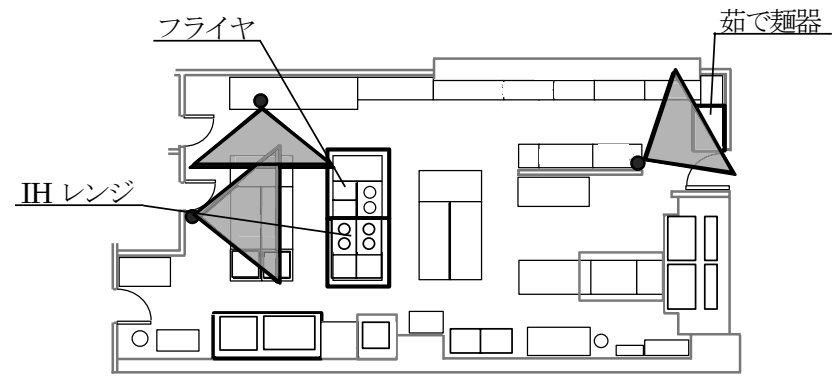

(d) 欴房 D

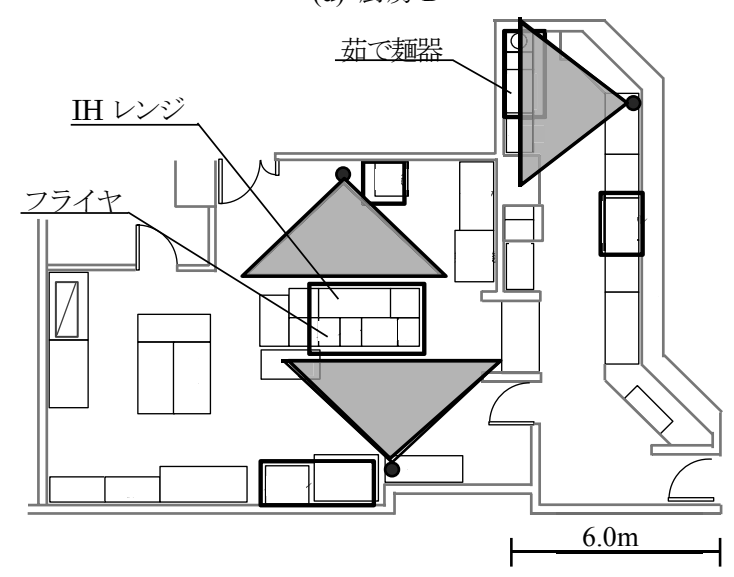

(e) 时房 $\mathrm{E}$

図 2 各厨房(厨房 $\mathrm{A} \sim \mathrm{E}$ )の平面図およびビデオカメラ設置位置 


\section{3 解析方法}

\section{1 解析対象とした調理機器}

調理行動の内容や頻度は調理機器と時間帯により異なる。本研究で は人体擾乱の影響を受けやすく、使用頻度が高い開放型調理機器を解 析対象とした。すなわち、IH レンジ、電気茹で麺器(以下、茹で麺器 と記す)、電気フライヤ(以下、フライヤと記す)の 3 種類の調理機器を 対象とする。

\section{2 解析対象とした時間}

各調理機器における繁忙時間帯に着目して検討することとした。前 述の 3 種類の調理機器の繁忙時間帯の継続時間は 30 分間程度かそれ 以上であると考え、繁忙時の 30 分を解析対象とした。すなわち、調 理機器前を撮影した動画の目視により、調理機器の稼働状況と調理者 の作業状況から、『対象とする調理機器が稼働しており、機器前作業 時間が最も長く、連続した 30 分間』を抽出し、解析対象とした。

\section{3 解析対象とした調理行動}

調理機器上の熱上昇流の擾乱となると考えられる調理者の行動と して、調理機器前の『通過』、調理機器前から『遠ざかる』、調理機器

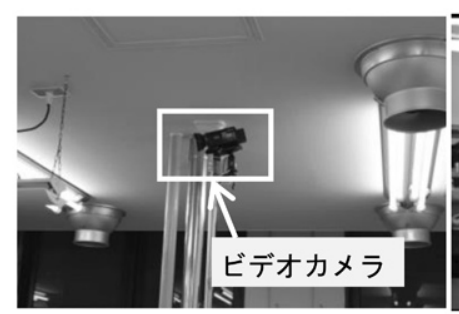

図 3 ビデオカメラ設置状況

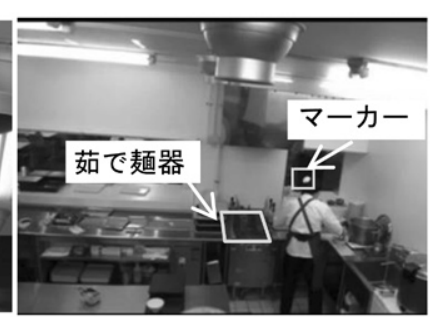

図 4 撮影画像の例 (厨房 A 茹で麺器前)
表 2 調理行動の回数・時間などの定義

\begin{tabular}{|c|c|}
\hline 通過の回数 & 調理機器前を停止することなく通過する回数 \\
\hline 遠ざかる回数 & $\begin{array}{l}\text { 調理担当者が調理機器前での作業から他の位置 } \\
\text { へ移動するため、調理機器前から遠ざかる回数 }\end{array}$ \\
\hline 近づく回数 & $\begin{array}{l}\text { 調理機器前作業をするために、調理担当者が調理 } \\
\text { 機器前に近づく回数を数える。 }\end{array}$ \\
\hline $\begin{array}{c}\text { 調理機器前の } \\
\text { 作業時間 } \\
\end{array}$ & $\begin{array}{l}\text { 近づく行動が終わり、遠ざかる行動が始まるまで } \\
\text { の時間 }\end{array}$ \\
\hline 投入回数 & 調理材料などが投入される回数 \\
\hline 取り出し回数 & 調理したものが取り出される回数 \\
\hline
\end{tabular}

表 3 動画解析ソフトにより歩行速度を求める際の時刻 $t_{s}, t_{e}$

\begin{tabular}{|c|c|c|}
\hline \multirow{2}{*}{ 通過 } & $t_{s}$ & $\begin{array}{l}\text { 通過する際、調理機器前領域の端部に進入し始めた } \\
\text { 時刻 } \\
\end{array}$ \\
\hline & $t_{e}$ & 通過する際、調理機器前領域の端部から出た時刻 \\
\hline \multirow[b]{2}{*}{ 遠ざかる } & $t_{s}$ & $\begin{array}{l}\text { 調理機器前での作業から他の位置へ移動するため、 } \\
\text { 調理機器前から遠ざかり始めた時刻 }\end{array}$ \\
\hline & $t_{e}$ & $\begin{array}{l}\text { 遠ざかり始めてから調理担当者の足が止まった(方向 } \\
\text { 転換した)時刻、あるいは、止まらずに画面上から消 } \\
\text { えた時刻 }\end{array}$ \\
\hline \multirow[t]{2}{*}{ 近づく } & $t_{s}$ & $\begin{array}{l}\text { 調理機器前に近づく際、調理者が画面上にいる場合 } \\
\text { は足が動き始めた時刻、いない場合は画面上に現れた時 } \\
\text { 刻 }\end{array}$ \\
\hline & $t_{e}$ & $\begin{array}{l}\text { 調理機器前に、機器前作業をするために近づき終え、 } \\
\text { 足が止まった時刻 }\end{array}$ \\
\hline
\end{tabular}

前へ『近づく』、『調理機器前の作業』、調理機器前作業での食材の『投 入』、取り出し』の 6 種類の行動に着目寸る。

\section{4 調理行動の回数・時間の調査方法}

調理行動の回数・時間を表 2 のように定義し、動画の目視により調 理行動を調査する。

\section{5 調理者の歩行速度の解析方法}

歩行速度は動画解析ソフト(Dipp-motion, カトウ光研)により解析 する。このソフトでは動画内で動かない物体(例えば、テーブル)の角 などで位置座標が明確な点を複数点指定することにより、他の位置座 標を画像変換技術により算出することができる。

本研究では、図 4 に示すように調理者の頭部に球状のマーカーを付 け、これを動画解析ソフトにより追跡し、各時点での調理者の位置座 標 $(x, y)$ を求める。各行動における時刻は動画の記録から特定すること ができ、各行動の開始と終了の時刻と位置座標が求められる。

本研究では『通過』、『遠ざかる』、『近づく』においてその行動の開 始時刻 $t_{s}$ とその終了時刻 $t_{e}$ を表 3 のように定義する。また、 $t_{s}$ 時点 の位置を $\left(x_{s}, y_{s}\right) 、 t_{e}$ 時点の位置を $\left(x_{e}, y_{e}\right)$ とし、式(1)〜式(3)により歩 行速度 $v$ を求める。

$v_{x}=\frac{x_{e}-x_{s}}{t_{e}-t_{s}}(1) \quad v_{y}=\frac{y_{e}-y_{s}}{t_{e}-t_{s}}(2) \quad v=\sqrt{v_{x}^{2}+v_{y}^{2}}$

ここで、 $v_{x}: \mathrm{X}$ 軸方向の速度 $[\mathrm{m} / \mathrm{s}] 、 v_{y}: \mathrm{Y}$ 軸方向の速度 $[\mathrm{m} / \mathrm{s}]$ 。

なお、 $t_{s}$ と $t_{e}$ は動画の観察により求め、その位置座標を動画解析 ソフトにより求めた。

\section{4 調理行動と歩行速度の解析結果}

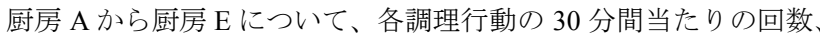
歩行速度、機器前作業時間を解析した結果を表 4 および図 5 に示寸。 また、厨房 $\mathrm{A}$ から厨房 $\mathrm{E}$ の結果を集計し、最大・最小・平均を算出 した結果を表 5 に示寸。なお、厨房 $\mathrm{B}$ と厨房 $\mathrm{D}$ では茹で麺器は厨房 端部にあったため、作業者が茹で麺器前を通過することはなかった。

『通過』、『遠ざかる』、『近づく』の回数を見ると(図 5(a) (c)中の棒 グラフ)、茹で麺器前を『遠ざかる』、『近づく』の回数が IH レンジや フライヤに比べ多い傾向が見られる。また、調理機器に関わらず『通 過』の回数は『遠ざかる』、『近づく』の回数より少ない。『通過』、遠 ざかる』、近づく』の歩行速度を見ると(図 5(a) (c)中の折れ線グラフ)、

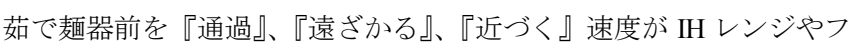
ライヤに比べやや速い傾向が見られる。

『機器前作業時間』はフライヤが長く、『投入/取り出し回数』もフ ライヤが多い傾向が見られる(図 5(d)〜(e))。

\section{1 通過}

『通過』の回数は厨房や調理機器により異なり、茹で麺器の前に調 理用器具などが置いてあった欴房 $\mathrm{B}$ と、茹で麺器が厨房の隅にある 厨房 $\mathrm{D}$ では 0 であった。表 5 に示寸厨房 $\mathrm{A}$ 嘚房 $\mathrm{E}$ の平均では $\mathrm{IH} レ$ ンジとフライヤの前を通過する回数は 30 分間で約 9 回であり、茹で 麺器では約 5 回であった。『通過』時の歩行速度は『遠ざかる』や『近 づく』に比べ速く、1.37 1.52m/s であった。 


\section{2 遠ざかる/近づく}

提供食数が多い厨房 D と㕑房 E では茹で曙器前で『遠ざかる/近づ く』の回数が多い。表 5 の平均では、IH レンジ前で約 22 回、茹で麺 器前で約 40 回、フライヤ前で約 15 回であった。歩行速度は『遠ざか る』と『近づく』で大きな差はなく、1.13 1.37m/s であった。

\section{3 機器前作業時間}

機器前作業時間は提供食数が多い厙房 D では茹で麺器で長い傾向 が見られ、解析対象時間 30 分中で 24 分以上調理者が作業していた。
フライヤ前の作業時間も長く、砶房 $\mathrm{E}$ では最大で 25 分以上であった。 これは調査した日の調理メニューに天ぷら・揚げ物が多かったためと 考えられる。表 5 の平均では、IH レンジ前で約 10 分、茹で麺器前で 約 14 分、フライヤ前で約 16 分であった。

\section{4 投入/取り出し回数}

フライヤと茹で麺器で『投入/取り出し』の回数が多い傾向が見ら れる。また、『機器前作業時間』の長さと『投入/取り出し』の回数に は対応関係が見られる。

表 4 各厨房(厨房 $\mathrm{A} \sim$ 厨房 E)における調理行動の解析結果

\begin{tabular}{|c|c|c|c|c|c|c|c|c|c|c|c|c|c|c|c|c|c|}
\hline & & & \multicolumn{3}{|c|}{ 厨房 A } & \multicolumn{3}{|c|}{ 厨房 B } & \multicolumn{3}{|c|}{ 厨房 C } & \multicolumn{3}{|c|}{ 厨房 D } & \multicolumn{3}{|c|}{ 厨房 $\mathrm{E}$} \\
\hline & & & 最大 & 最小 & 平均 & 最大 & 最小 & 平均 & 最大 & 最小 & 平均 & 最大 & 最小 & 平均 & 最大 & 最小 & 平均 \\
\hline \multirow{6}{*}{$\mathrm{IH}$} & \multirow{2}{*}{ 通過 } & 回数 [回/30 分] & 17 & 6 & 11.5 & 11 & 6 & 8.5 & 11 & 6 & 8.8 & 20 & 11 & 15.5 & 1 & 0 & 0.5 \\
\hline & & 歩行速度 $[\mathrm{m} / \mathrm{s}]$ & 2.08 & 1.00 & 1.60 & 2.44 & 1.05 & 1.62 & 1.82 & 0.95 & 1.32 & 1.69 & 0.69 & 1.11 & 1.20 & 1.20 & 1.20 \\
\hline & \multirow{2}{*}{ 遠ざかる } & 回数 [回/30 分] & 13 & 12 & 12.5 & 41 & 20 & 30.5 & 26 & 19 & 22.5 & 29 & 11 & 20 & 27 & 10 & 23.5 \\
\hline & & 歩行速度[m/s] & 2.31 & 0.47 & 1.25 & 2.06 & 0.75 & 1.46 & 2.06 & 0.36 & 1.27 & 1.04 & 0.51 & 0.70 & 1.54 & 0.30 & 1.00 \\
\hline & \multirow{2}{*}{ 近づく } & 回数 [回/30 分] & 13 & 12 & 12.5 & 41 & 20 & 30.5 & 25 & 19 & 22.3 & 29 & 11 & 20 & 27 & 10 & 23.5 \\
\hline & & 歩行速度 $[\mathrm{m} / \mathrm{s}]$ & 2.27 & 0.52 & 1.35 & 2.08 & 0.73 & 1.40 & 3.23 & 0.33 & 1.19 & 1.11 & 0.45 & 0.72 & 1.42 & 0.40 & 1.00 \\
\hline ジ & \multicolumn{2}{|c|}{ 機器前作業時間 } & $\begin{array}{r}6 \text { 分 } \\
17 \text { 秒 } \\
\end{array}$ & $\begin{array}{r}5 \text { 分 } \\
32 \text { 秒 }\end{array}$ & $\begin{array}{r}5 \text { 分 } \\
55 \text { 秒 } \\
\end{array}$ & $\begin{array}{r}11 \text { 分 } \\
0 \text { 秒 } \\
\end{array}$ & $\begin{array}{r}5 \text { 分 } \\
21 \text { 秒 } \\
\end{array}$ & $\begin{array}{r}8 \text { 分 } \\
11 \text { 秒 }\end{array}$ & $\begin{array}{r}18 \text { 分 } \\
2 \text { 秒 } \\
\end{array}$ & $\begin{array}{l}4 \text { 分 } \\
6 \text { 秒 }\end{array}$ & $\begin{array}{r}9 \text { 分 } \\
21 \text { 秒 }\end{array}$ & $\begin{array}{r}10 \text { 分 } \\
5 \text { 秒 } \\
\end{array}$ & $\begin{array}{r}3 \text { 分 } \\
51 \text { 秒 }\end{array}$ & $\begin{array}{r}6 \text { 分 } \\
58 \text { 秒 } \\
\end{array}$ & $\begin{array}{r}20 \text { 分 } \\
1 \text { 秒 }\end{array}$ & $\begin{array}{l}18 \text { 分 } \\
56 \text { 秒 }\end{array}$ & $\begin{array}{l}19 \text { 分 } \\
29 \text { 秒 }\end{array}$ \\
\hline & \multicolumn{2}{|c|}{ 投入回数 [回/30 分] } & 6 & 3 & 4.5 & 26 & 5 & 15.5 & 30 & 9 & 19.3 & 27 & 0 & 13.5 & 11 & 10 & 10.5 \\
\hline & \multicolumn{2}{|c|}{ 取り出し回数 [回/30 分] } & 22 & 0 & 11 & 16 & 9 & 12.5 & 43 & 2 & 13.8 & 25 & 0 & 12.5 & 12 & 0 & 6 \\
\hline \multirow{9}{*}{$\begin{array}{l}\text { 茹 } \\
\text { で } \\
\text { 麺 }\end{array}$} & \multirow{2}{*}{ 通過 } & 回数 [回/30 分] & 17 & 14 & 15.5 & 0 & 0 & 0 & 9 & 7 & 8 & 0 & 0 & 0 & 3 & 3 & 3 \\
\hline & & 歩行速度 [m/s] & 2.39 & 0.93 & 1.60 & - & - & - & 3.10 & 0.92 & 1.79 & - & - & - & 1.41 & 0.86 & 1.18 \\
\hline & \multirow{2}{*}{ 遠ざかる } & 回数 [回/30 分] & 26 & 18 & 22 & 33 & 23 & 26.7 & 24 & 23 & 23.5 & 64 & 51 & 57.5 & 73 & 64 & 68.5 \\
\hline & & 歩行速度 $[\mathrm{m} / \mathrm{s}]$ & 3.39 & 0.91 & 1.58 & 2.36 & 0.30 & 1.47 & 2.39 & 0.71 & 1.54 & 2.88 & 0.81 & 1.35 & 2.48 & 0.19 & 0.91 \\
\hline & \multirow{2}{*}{ 近づく } & 回数 [回/30 分] & 26 & 18 & 22 & 33 & 23 & 26.7 & 24 & 23 & 23.5 & 64 & 51 & 57.5 & 73 & 64 & 68.5 \\
\hline & & 歩行速度 $[\mathrm{m} / \mathrm{s}]$ & 2.60 & 0.78 & 1.39 & 2.60 & 0.15 & 1.37 & 2.77 & 0.58 & 1.34 & 2.88 & 0.54 & 1.40 & 2.16 & 0.31 & 1.11 \\
\hline & \multicolumn{2}{|c|}{ 機器前作業時間 } & $\begin{array}{l}13 \text { 分 } \\
15 \text { 秒 } \\
\end{array}$ & $\begin{array}{l}\text { 分 } \\
1 \text { 秒 }\end{array}$ & $\begin{array}{r}9 \text { 分 } \\
38 \text { 秒 } \\
\end{array}$ & \begin{tabular}{|l|}
13 \\
31 分 \\
\end{tabular} & $\begin{array}{r}9 \text { 分 } \\
33 \text { 秒 } \\
\end{array}$ & $\begin{array}{l}11 \text { 分 } \\
28 \text { 秒 } \\
\end{array}$ & $\begin{array}{r}8 \text { 分 } \\
20 \text { 秒 } \\
\end{array}$ & $\begin{array}{r}7 \text { 分 } \\
47 \text { 秒 } \\
\end{array}$ & $\begin{array}{l}8 \text { 分 } \\
4 \text { 秒 } \\
\end{array}$ & $\begin{array}{l}24 \text { 分 } \\
24 \text { 秒 } \\
\end{array}$ & $\begin{array}{r}24 \text { 分 } \\
8 \text { 秒 } \\
\end{array}$ & $\begin{array}{l}24 \text { 分 } \\
16 \text { 秒 } \\
\end{array}$ & $\begin{array}{l}16 \text { 分 } \\
56 \text { 秒 }\end{array}$ & $\begin{array}{l}13 \text { 分 } \\
12 \text { 秒 } \\
\end{array}$ & $\begin{array}{r}15 \text { 分 } \\
4 \text { 秒 } \\
\end{array}$ \\
\hline & \multicolumn{2}{|c|}{ 投入回数 [回/30 分] } & 16 & 11 & 13.5 & 34 & 15 & 23 & 11 & 10 & 10.5 & 98 & 45 & 71.5 & 34 & 27 & 30.5 \\
\hline & \multicolumn{2}{|c|}{ 取り出し回数 [回/30 分] } & 16 & 11 & 13.5 & 34 & 15 & 23 & 11 & 10 & 10.5 & 98 & 45 & 71.5 & 34 & 27 & 30.5 \\
\hline \multirow{9}{*}{$\begin{array}{l}\text { ㄱ } \\
\text { ज } \\
\text { 1 } \\
\text { ヤ }\end{array}$} & \multirow{2}{*}{ 通過 } & 回数 [回/30 分] & 12 & 7 & 9.5 & 17 & 14 & 15.5 & 11 & 4 & 7.5 & 10 & 5 & 7.5 & 1 & 0 & 0.5 \\
\hline & & 歩行速度 $[\mathrm{m} / \mathrm{s}]$ & 2.44 & 1.25 & 1.73 & 2.28 & 0.76 & 1.73 & 2.37 & 0.98 & 1.68 & 1.68 & 0.64 & 1.11 & 1.61 & 0.70 & 1.00 \\
\hline & \multirow{2}{*}{ 遠ざかる } & 回数 [回/30 分] & 20 & 16 & 18 & 18 & 10 & 14 & 17 & 13 & 15 & 16 & 10 & 13 & 27 & 7 & 17 \\
\hline & & 歩行速度 $[\mathrm{m} / \mathrm{s}]$ & 2.02 & 0.56 & 1.36 & 2.12 & 0.67 & 1.32 & 2.44 & 0.58 & 1.54 & 1.30 & 0.50 & 0.87 & 2.02 & 0.60 & 1.12 \\
\hline & \multirow{2}{*}{ 近づく } & 回数 [回/30 分] & 20 & 16 & 18 & 18 & 10 & 14 & 17 & 13 & 15 & 16 & 10 & 13 & 28 & 8 & 18 \\
\hline & & 歩行速度 $[\mathrm{m} / \mathrm{s}]$ & 1.88 & 0.75 & 1.36 & 2.43 & 0.40 & 1.18 & 2.13 & 0.17 & 1.10 & 1.34 & 0.31 & 0.83 & 2.33 & 0.34 & 0.90 \\
\hline & \multicolumn{2}{|c|}{ 機器前作業時間 } & $\begin{array}{l}19 \text { 分 } \\
31 \text { 秒 }\end{array}$ & $\begin{array}{l}15 \text { 分 } \\
23 \text { 秒 }\end{array}$ & $\begin{array}{l}17 \text { 分 } \\
27 \text { 秒 }\end{array}$ & $\begin{array}{l}16 \text { 分 } \\
35 \text { 秒 }\end{array}$ & $\begin{array}{l}11 \text { 分 } \\
42 \text { 秒 }\end{array}$ & $\begin{array}{r}14 \text { 分 } \\
8 \text { 秒 }\end{array}$ & $\begin{array}{l}20 \text { 分 } \\
51 \text { 秒 }\end{array}$ & $\begin{array}{r}7 \text { 分 } \\
27 \text { 秒 }\end{array}$ & $\begin{array}{r}14 \text { 分 } \\
9 \text { 秒 }\end{array}$ & $\begin{array}{l}18 \text { 分 } \\
48 \text { 秒 }\end{array}$ & $\begin{array}{l}5 \text { 分 } \\
4 \text { 秒 }\end{array}$ & $\begin{array}{l}11 \text { 分 } \\
56 \text { 秒 }\end{array}$ & $\begin{array}{l}25 \text { 分 } \\
46 \text { 秒 }\end{array}$ & $\begin{array}{l}18 \text { 分 } \\
21 \text { 秒 }\end{array}$ & $\begin{array}{r}22 \text { 分 } \\
4 \text { 秒 }\end{array}$ \\
\hline & \multicolumn{2}{|c|}{ 投入回数 [回/30 分] } & 68 & 29 & 48.5 & 55 & 35 & 45 & 135 & 60 & 97.5 & 17 & 11 & 14 & 133 & 63 & 98 \\
\hline & \multicolumn{2}{|c|}{ 取り出し回数 [回/30 分] } & 30 & 20 & 25 & 28 & 18 & 23 & 90 & 68 & 79 & 47 & 23 & 35 & 29 & 28 & 28.5 \\
\hline
\end{tabular}

表 5 調理行動の解析結果(欴房 $\mathrm{A} \sim \mathrm{E}$ の最大・最小・平均)

\begin{tabular}{|c|c|c|c|c|c|c|c|c|c|c|}
\hline & & \multicolumn{3}{|c|}{ IH レンジ } & \multicolumn{3}{|c|}{ 茹で麺器 } & \multicolumn{3}{|c|}{ フライヤ } \\
\hline & & 最大 & 最小 & 平均 & 最大 & 最小 & 平均 & 最大 & $\begin{array}{l}\text { 最小 } \\
\end{array}$ & 平均 \\
\hline \multirow{2}{*}{ 通過 } & 回数 [回/30 分] & 20 & 0 & 9.0 & 17 & 0 & 5.3 & 17 & 0 & 8.1 \\
\hline & 歩行速度 $[\mathrm{m} / \mathrm{s}]$ & 2.44 & 0.69 & 1.37 & 3.1 & 0.81 & 1.52 & 2.44 & 0.64 & 1.45 \\
\hline \multirow{2}{*}{ 遠ざかる } & 回数 [回/30 分] & 41 & 10 & 21.8 & 73 & 18 & 39.6 & 27 & 8 & 15.4 \\
\hline & 歩行速度 [m/s] & 2.31 & 0.3 & 1.14 & 3.39 & 0.19 & 1.37 & 2.44 & 0.5 & 1.19 \\
\hline \multirow{2}{*}{ 近づく } & 回数 [回/30 分] & 41 & 10 & 21.8 & 73 & 18 & 39.6 & 28 & 8 & 15.6 \\
\hline & 歩行速度 $[\mathrm{m} / \mathrm{s}]$ & 3.23 & 0.33 & 1.13 & 2.77 & 0.15 & 1.32 & 2.43 & 0.17 & 1.07 \\
\hline \multicolumn{2}{|c|}{ 機器前作業時間 } & 20 分 1 秒 & 3 分 51 秒 & 9 分 52 秒 & 24 分 24 秒 & 5 分 49 秒 & 13 分 42 秒 & 25 分 46 秒 & 5 分 4 秒 & 15 分 57 秒 \\
\hline \multicolumn{2}{|c|}{ 投入回数 [回/30 分] } & 30 & 0 & 12.7 & 98 & 10 & 29.8 & 135 & 11 & 60.6 \\
\hline \multicolumn{2}{|c|}{ 取り出し回数 [回/30 分] } & 43 & 0 & 11.2 & 98 & 10 & 29.8 & 90 & 18 & 38.1 \\
\hline
\end{tabular}




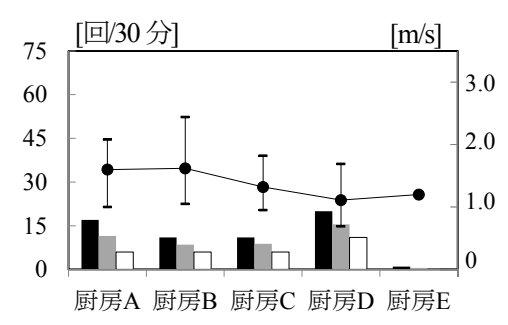

(a-1) IH レンジ

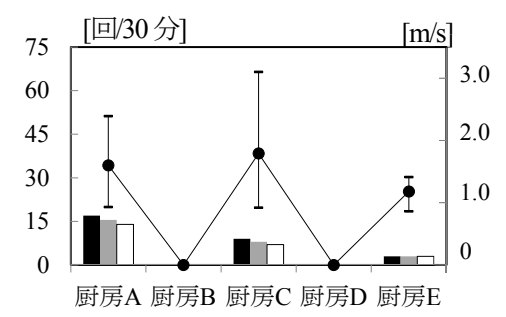

(a-2) 茹で麺器

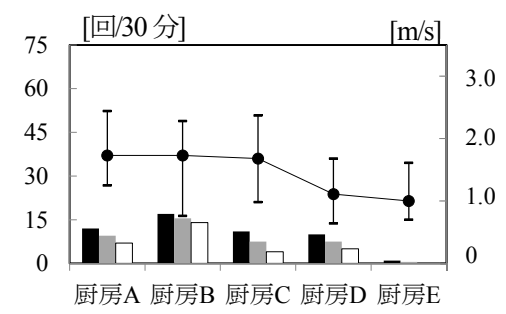

(a-3) フライヤ

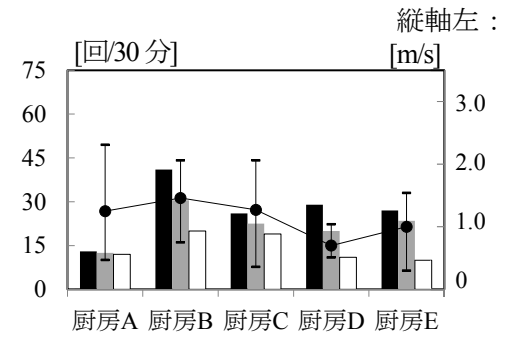

(b-2) IH レンジ

軸左 : 回数, 縦軸右 : 歩行速度 / 棒グラフ

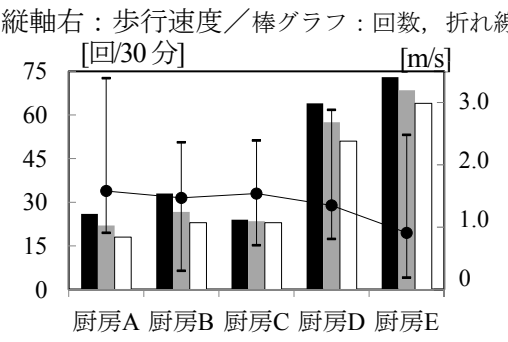

(b-2) 茹で麺器

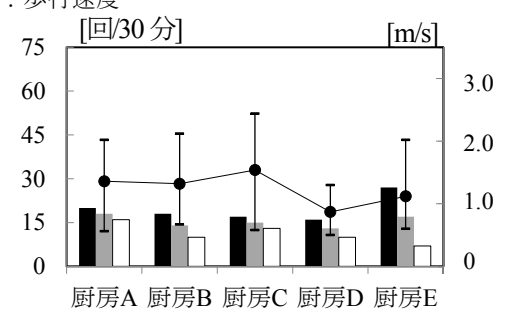

(b-3) フライヤ

$$
\text { (b) 遠ざかる }
$$

縦軸左 : 回数, 縦軸右 : 歩行速度/棒グラフ : 回数, 折れ線グラフ : 歩行速度

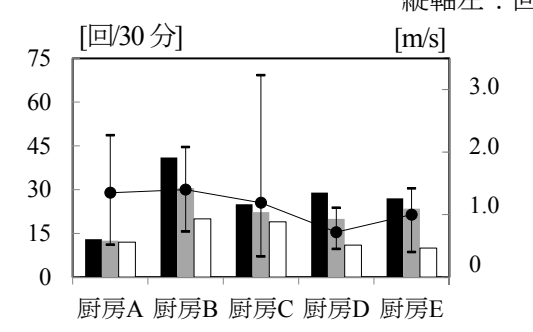

(c-1) IH レンジ

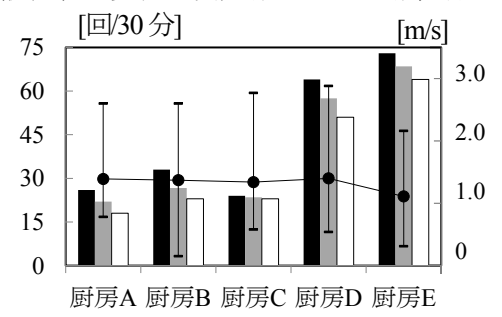

(c-2) 茹で麺器

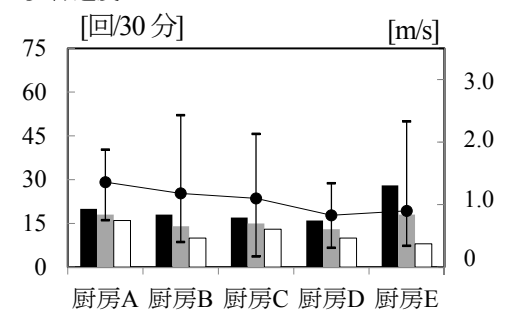

(c-3) フライヤ

縦軸左 : 回数, 縦軸右 : 歩行速度 / 棒グラフ : 回数, 折れ線グラフ : 歩行速度

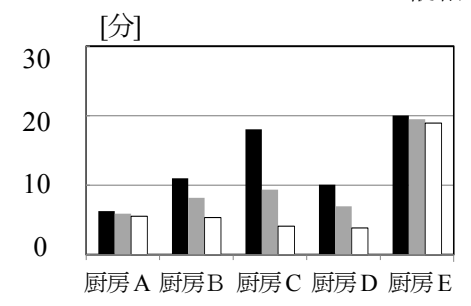

(d-1) IH レンジ

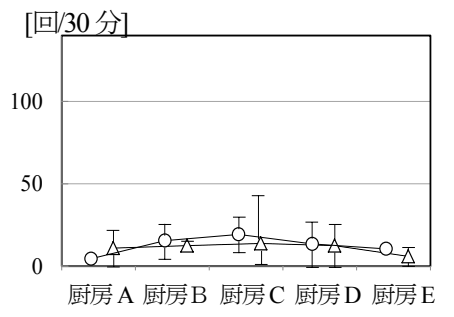

(e-1) IH レンジ

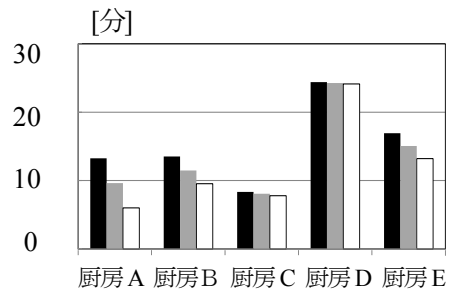

(d-2) 茹で麺器

(d) 機器前作業時間

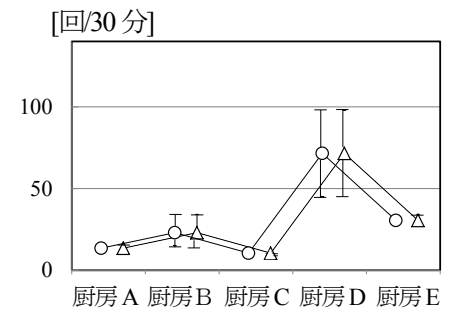

(e-2) 茹で麺器

(e) 投入/取り出し回数

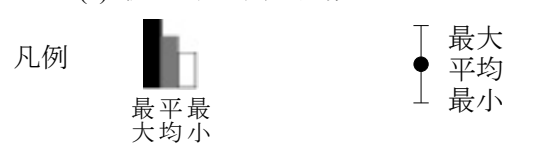

(i) 行動回数 (ii) 歩行速度

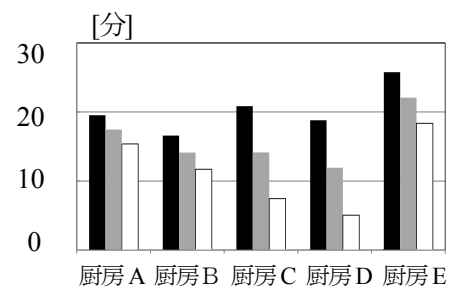

(d-3) フライヤ

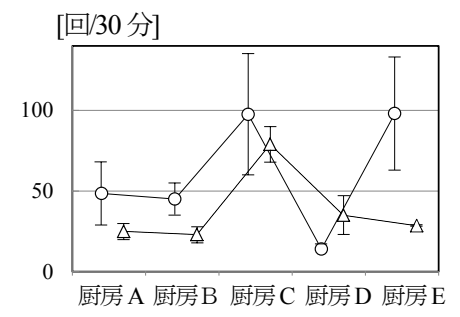

(e-3) フライヤ
最大
平均
最小

(iii) 投入回数 (iv) 取り出し回数

図 5 各厨房(厨房 $\mathrm{A} \sim \mathrm{E}$ )における調理行動の解析結果 


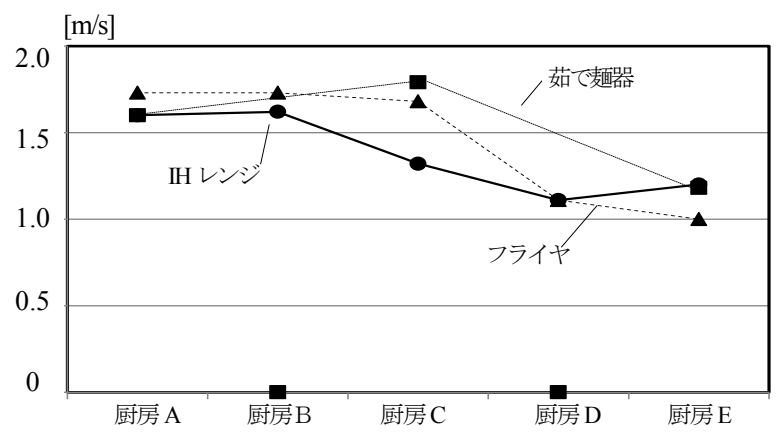

(a) 『通過』時の平均歩行速度

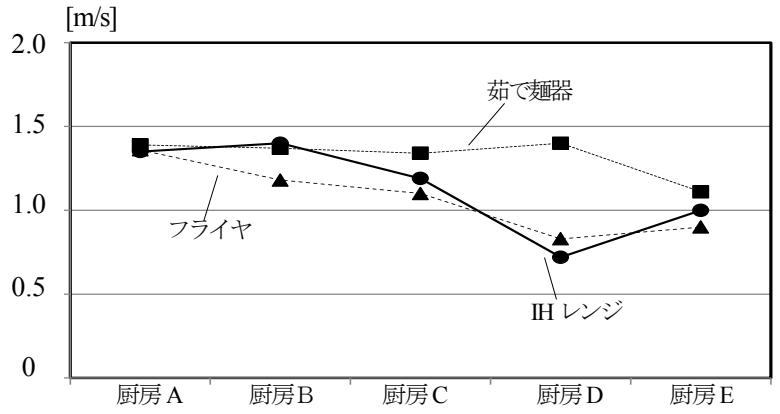

(b) 『近づく』時の平均歩行速度

\begin{tabular}{|c|c|c|c|c|c|c|c|c|c|c|}
\hline & \multicolumn{2}{|c|}{ 並房 A } & \multicolumn{2}{|c|}{ 厥房 B } & \multicolumn{2}{|c|}{ 㕌房 $\mathrm{C}$} & \multicolumn{2}{|c|}{ 厨房 D } & \multicolumn{2}{|c|}{ 影房 $\mathrm{E}$} \\
\hline 床面積 & \multicolumn{2}{|c|}{$75.8 \mathrm{~m}^{2}$} & \multicolumn{2}{|c|}{$111.8 \mathrm{~m}^{2}$} & \multicolumn{2}{|c|}{$70.0 \mathrm{~m}^{2}$} & \multicolumn{2}{|c|}{$97.0 \mathrm{~m}^{2}$} & \multicolumn{2}{|c|}{$127.0 \mathrm{~m}^{2}$} \\
\hline 設計食数 & \multicolumn{2}{|c|}{ 約 200 食 } & \multicolumn{2}{|c|}{ 約 800 食 } & \multicolumn{2}{|c|}{ 約 200 食 } & \multicolumn{2}{|c|}{ 約 400 食 } & \multicolumn{2}{|c|}{ 約 200 食 } \\
\hline \multirow{2}{*}{ 提供食数 } & $12 / 12$ & $12 / 13$ & $12 / 5$ & $12 / 6$ & $11 / 12$ & $11 / 13$ & $12 / 13$ & $12 / 14$ & $12 / 4$ & $12 / 5$ \\
\hline & 78 食 & 73 食 & 95 食 & 165 食 & 145 食 & 140 食 & 324 & 294 冝 & 193 食 & 185 食 \\
\hline 作業人数 & \multicolumn{2}{|c|}{3 人 } & \multicolumn{2}{|c|}{2 人 } & \multicolumn{2}{|c|}{7 人 } & \multicolumn{2}{|c|}{ 7人 } & \multicolumn{2}{|c|}{ 6人 } \\
\hline
\end{tabular}

図 6 㕌房毎の『通過』および『近づく』時の平均歩行速度

\section{5 歩行速度と床面積 - 提供食数 - 作業人数との関係}

『通過』時と『近づく』時の平均歩行速度に着目し、床面積・提供 食数・作業人数との関係を検討する。図 6 に㕌房毎の平均歩行速度を 示し、図 7 に平均歩行速度と床面積・提供食数・作業人数との相関関 係を示す。

作業人数は 1 人の差であるが、床面積に約 $50 \mathrm{~m}^{2}$ の差がある㕌房 $\mathrm{C}$ と厨房 $\mathrm{E}$ を比較すると、図 6 からわかるように床面積の小さい厨房 $\mathrm{C}$ では床面積の大きい影房 $\mathrm{E}$ より『通過』時の平均歩行速度がやや速 いが、『近づく』では差異は顕著でない。この傾向は図 7(a)にも表れ ており、『通過』時の平均歩行速度と床面積には負の相関関係が見ら れる。ただし、決定係数 $\left(\mathrm{R}^{2}\right)$ は小さく、相関は弱い。

作業人数が同じであるが、提供食数が異なる厨房 $\mathrm{C}$ と厨房 $\mathrm{D}$ を比 較すると、提供食数が多い欴房 $\mathrm{D}$ の歩行速度が痖房 C より速いと予 想されたが、図 6 の結果では厨房 $\mathrm{C}$ の歩行速度の方が速い場合が多 かった。㕌房 D では麺類の提供数が多く、図 2 に示寸ように茹で麺 器が厫房の隅の提供カウンタ近くに配置され、IH レンジとフライヤ が近くにあり作業者の動線が整理されている。一方、㕌房 C では使 用頻度の高いIH レンジ、フライヤが比較的離れており、茹で麺器は 提供カウンタの近くに無いことなどが歩行速度の差異に現れたと考 えられる。しかし、図7(b)では、平均歩行速度と提供食数には負の相 関関係が見られる。ただし、決定係数 $\left(\mathrm{R}^{2}\right)$ は比較的小さく、相関は弱
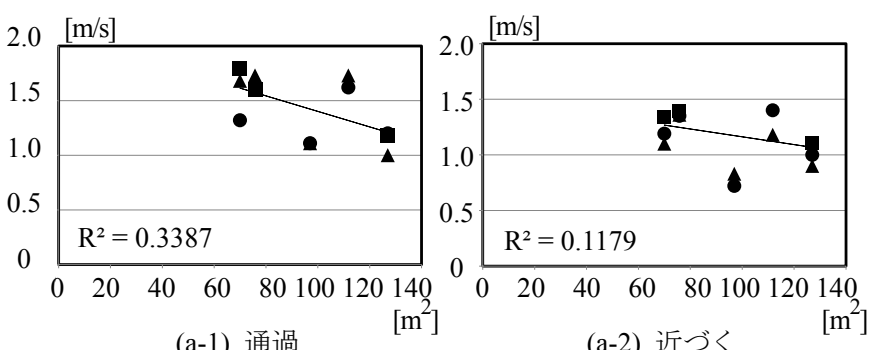
(a-1) 通過

(a) 床面積と平均歩行速度

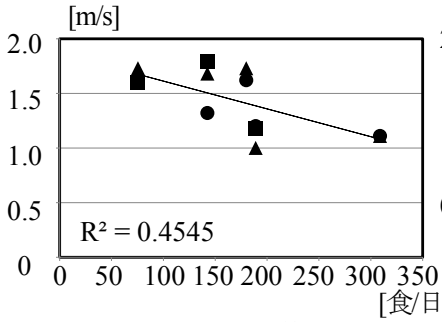

(b-1) 通過

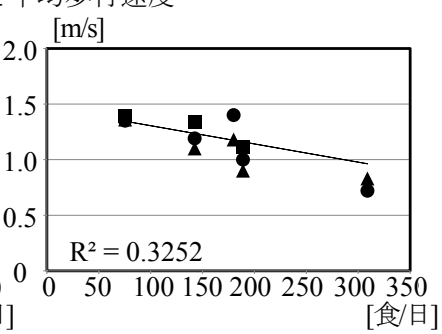

(b-2) 近づく (b) 提供食数と平均歩行速度

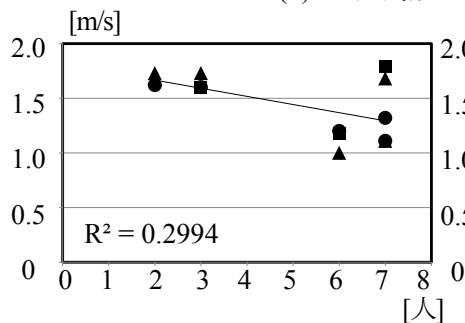

(c-1) 通過

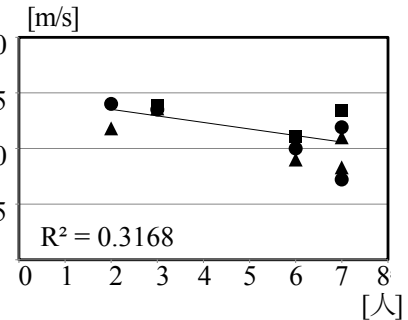

(c-2) 近づく (c) 作業人数と平均歩行速度

凡例・IH レンジ - 茹で麺器・フライヤ 図 7 平均歩行速度と床面積 - 提供食数 - 作業人数との相関関係

い。

図 6 の結果では作業人数が少ない厨房 A と㕌房 B では他の㕌房に 比べて歩行速度がやや速い傾向が見られる。これは一人たりの仕事 量が多いことによると推測される。ただし、作業人数が多い厨房 C においても調理機器によっては歩行速度が速い場合がある。また、図 7(c)では、作業人数と平均歩行速度には負の弱い相関関係が見られる。

\section{5 まとめ}

本研究では 5 つの中規模業務用電化厨房を対象に、調理行動を調査 し、その頻度と調理者の歩行速度などを動画により解析した。以下に 知見を示す。

（1）動画解析ソフトにより調理者の歩行速度を測定することができ る。

(2) 調理行動の回数(頻度)や調理者の歩行速度の解析結果にはばら つきがあるが、調理メニュー、提供食数、調理機器、作業人数、 床面積などによる傾向が把握できた。

（3）作業者の歩行速度の平均は『通過』時は約 $1.45 \mathrm{~m} / \mathrm{s}$ であり、『遠 ざかる/近づく』では約 $1.2 \mathrm{~m} / \mathrm{s}$ であり、Nordtest method VVS088 でのパネル移動速度 $(0.5 \mathrm{~m} / \mathrm{s})$ に比べ、調理者の歩行速度は速い。

（4）歩行速度は床面積、提供食数、作業人数に対し、負の弱い相関が 見られる。 


\section{謝辞}

本研究を行うにあたり、中部電力・宮崎博之氏、研究当時・東京都 市大学・鈴木盛永氏 (現、竹中工務店)、カトウ光研・藤村浩一氏をは じめ、多くの方々に多大なご協力を頂きました。ここに深く感謝の意 を表します。

\section{参考文献}

1）近藤靖史、長澤康弘、川瀬貴晴、永瀬修、石川登志樹、室田岳志、赤林伸一： 業務用ちゅう房におけるエネルギー消費量と換気・空調システム、空気調 和・衛生工学、第 75 巻、第 9 号、pp.761-770、2001.9

2) 近藤靖史、荻田俊輔、吉野一、藤田美和子 : 業務用電化厨房における置換換 気・空調システムに関する研究、日本建築学会環境系論文集、第 77 巻、第 676 号、pp.481-489、2012.3

3) Food Service Consultants International North America: Commercial Kitchen Ventilation, "Best Practice", Design and Specification Guidelines, 2006.9

4) Nordtest method VVS088:Building Large Scale Kitchen Range Hoods-Hood Efficiency and Pressure Drop, www.nordtest.org, 1990.9

5) 百瀬敏成、佐藤隆二、山中俊夫 : 業務用欴房の給排気設計に関する研究 (その 3）フライヤ調理時における横風の影響およびレンジにおける調理人移動の影 響、空気調和・衛生工学会学術講演会講演論文集、pp.1149-1152、1999.9

6) 荻田俊輔、近藤靖史、吉野一、川瀨隆晴、平田俊明 : 業務用欴房における置
換換気・空調方式に関する研究(その 1) 天井設置型吹出口による置換換気・ 空調方式の有效性の検討、日本建築学会環境系論文集、第 73 巻、第 628 号、 pp.759-766、2008.6

7) 近藤靖史、荻田俊輔、吉野一、藤田美和子、小笠原岳 : ファミリーレストラ ンの旡房換気に関寸る研究（第 1 報）CFD 解析と実験による局所空調方式 と天井給気型置換換気方式の比較、日本建築学会環境系論文集、第 77 巻、 第 682 号、pp.977-986、2012.12

8) Rong Fung Huang, Guan-Zhong Dai and Jia-Kun Chen: Effects of Mannequin and Walk-by Motion on Flow and Spillage Characteristics of Wall-Mounted and Jet-Isolated Range Hoods, Ann. Occp. Hyg., Vol. 54, No.6., pp.625-639, 2010.4

9) (財)ベターリビング : 電化厨房における必要換気量に関する基礎的研究報告 書、 1989.3

10）赤林伸一、坂口淳、富岡誠子、石山洋平 : 住宅用調理レンジを対象とした 排気フードの廃気捕集率に関する研究その 1、その 2、日本建築学会大会学 術講演梗概集 D-2 環境工学 II 、pp.715-718、2007.8

11) 近藤靖史、阿部有希子、大島敬典、相澤芳弘 : 住宅厥房と隣接するリビン グ空間の温熱・空気環境に関する研究 (第 1 報) 換気の給気位置と調理時の 擾乱による室内環境への影響に関する実験、日本建築学会環境系論文集、第 73 巻、第 627 号、pp.607-614、2008.5

12）倉㴊隆、鳥海吉弘、遠藤智行、坂本淳、奥田篤 : 住宅㷴房内の各種擾乱が 排気捕集率に及ぼす影響評価に関する研究、日本建築学会環境系論文集、第 76 卷、第 663 号、pp.493-500、2011.5

（2013年 7 月 5 日原稿受理，2014年 1 月14日採用決定） 